\title{
LAS JUNTAS Y DIPUTACIÓN PERMANENTE DE LA GRANDEZA DE ESPAÑA (1815-1833): UN INTENTO DE INTERVENCIÓN POLÍTICA CONJUNTA DE LA ALTA NOBLEZA'
}

The Assemblies and Permanent Deputation of the Spanish Greatness (1815-1833): An attempt of joint political intervention of the high nobility

\author{
ANTONIO MANUEL MORAL RONCAL \\ Universidad de Alcalá \\ antonio.moral@uah.es
}

Cómo citar/Citation

Moral Roncal, A. M. (2020)

Las Juntas y Diputación Permanente de la Grandeza de España (1815-1833)

un intento de intervención política conjunta de la alta nobleza.

Historia y Política, 43, 159-191.

doi: https://doi.org/10.18042/hp.43.06

(Recepción: 23/01/2019; evaluación: 13/05/2019; aceptación: 27/07/2019; publicación: 13/05/2020)

\section{Resumen}

Este estudio sitúa límites a la tradicional visión de una nobleza escasamente interesada en intervenir, de forma corporativa y unida, en la política española de las primeras décadas del siglo xıx. Se analiza la creación, gestión y organización de la Junta General de Grandes de 1815, ocasión que posibilitó la creación de su Diputación Permanente, que continuaría existiendo hasta la actualidad. Algunos

1 Este artículo se inscribe dentro del proyecto de investigación HAR2015-67753-P, titulado «Nobles, negociantes, políticos y redes cortesanas (España, 1788-1931)», del cual forma parte el autor. 
miembros de la alta nobleza intentaron utilizar ese organismo como herramienta para intervenir en política, defendiendo sus intereses y revalorizando su prestigio, al poder dirigirse directamente a la Corona en un reinado donde esta alcanzó las máximas cotas de decisión política de todo el siglo xIx. Si fue una estrategia fracasada, no por ello dejó de ser un importante intento de revalorizar el protagonismo político de la nobleza.

\title{
Palabras clave
}

España; siglo xıx; alta nobleza; Diputación Permanente; Junta de Grandes.

\begin{abstract}
This study tie down the traditional vision of a nobility scarcely interested in intervening, in a corporate and united way, in the Spanish politics at the first decade of the 19th century. The creation, management and organization of the General Assembly of Greatness (1815) is analyzed, an occasion that made possible the creation of his Permanent Deputation, which would continue to exist until today. Some members of the high nobility tried to use that organism as a tool to intervene in politics, defending their interests and revaluing their prestige, by being able to address directly to the Crown, in a reign where she reached the highest levels of political rule of the entire nineteenth century. If it was a failed strategy, not for it being an important attempt to revalue the nobility's political protagonism.
\end{abstract}

\section{Keywords}

Spain; 19th century; high nobility; Permanent Deputation; Assembly of Greatness. 
I.INTRODUCCIÓN. II. UNA OPORTUNIDAD INESPERADA. III. SE INTENTA SU INSTITUCIONALIZACIÓN POLIITICA. IV. DEFENSA DE LA DISTINCIÓN. V. UN PROBLEMA NOBILIARIO: LA INDEFINICIÓN DE LA CUESTIÓN SEÑORIAL. VI. VALES, LANZAS Y MEDIAS ANATAS. VII. CONCLUSIÓN: UNA ESTRATEGIA POLÍTICA FRACASADA. BIBLIOGRAFÍA.

\section{INTRODUCCIÓN}

Habitualmente se ha afirmado que la alta nobleza se adaptó a los cambios de la revolución liberal en España, por lo cual tuvo una general actitud de inhibición, en el campo político, mientras no fueran amenazados sus intereses económicos, de tal manera que adoptó un talante político conservador, pero adaptable a cambios de circunstancias ${ }^{2}$. En 1814 Fernando VII, rey por aclamación popular, no precisaba esencialmente del apoyo de la grandeza ni consideraba que debiera especialmente a ella la recuperación del trono, pero la mayoría de sus miembros aceptaron la abolición de la Constitución gaditana, aunque hubo también jóvenes aristócratas que fueron ganados por la causa liberal. Nuevamente, la nobleza parecía un sector que ni estaba unido ni tenía un claro programa político, aunque no podía abandonar las instituciones de poder pues ello supondría su anulación y desaparición ${ }^{3}$. Como veremos, esa visión debe matizarse pues hubo grandes que trataron de aprovechar la aparición de una asamblea en 1815 que debía reunir en común a toda la grandeza — su Junta General— que eligió, a su vez, a una Diputación, convertida en representación permanente cerca del epicentro del poder político: la Corona.

2 Bullón de Mendoza (2014); Cuenca Toribio y Miranda García (1998); La Parra (2007); Martínez Quinteiro (1977); Morange (1984), y Moral Roncal (2015). Una nobleza que no pudo evitar dejar de ser estamento para convertirse en una parte más de las élites de la sociedad liberal, como subrayaron Pro $(1994,1995)$ y Cruz (1994, 1996). No se trata, sin embargo, de un grupo social totalmente cerrado a ciertos cambios, pues si bien defendió a ultranza sus valores, aceptó igualmente cuantos elementos modernizadores le sirviesen para mantener sus posiciones, como señala Carrasco (1995). Un ejemplo fue la apuesta de varios nobles por el proyecto josefino, analizada por Risco (2010). Por su parte, la nobleza americana, en pleno proceso de independencia, aumentó su presencia en la corte y en los organismos de gobiernos en esta época, como demuestra Moral (2002).

3 Powis (2007): 128. 
El presente estudio analiza, por primera vez, ese intento de intervención política conjunta durante el reinado de Fernando VII, basándose en diversas fuentes tanto bibliográficas como archivísticas. El archivo de la Diputación de la Grandeza fue destruido en la Guerra Civil, aunque en vísperas se lograron

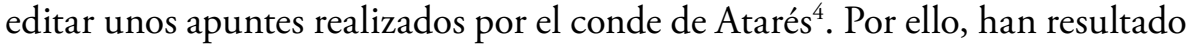
vitales para esta investigación los documentos inéditos de la misma encontrados en el Archivo del Palacio Real de Madrid, así como otros relacionados con la grandeza provenientes de la misma fuente y del Archivo Histórico de la Nobleza en Toledo. Como han señalado Mosse y Wasson, si el papel y la estructura que desempeńó la aristocracia del siglo xIx fueron, especialmente, productos de factores políticos, el estudio de las relaciones entre la nobleza y la Corona adquieren especial relevancia. De ahí que tratemos de aportar esta investigación a las existentes sobre la nobleza europea ${ }^{5}$.

\section{UNA OPORTUNIDAD INESPERADA}

El origen de la Junta de la Diputación Permanente de la Grandeza se encuentra en la convocatoria que Fernando VII ordenó realizar, el 15 de mayo de 1815, a los duques del Infantado y de San Carlos. Su objetivo fue solicitar a la alta nobleza que, como primera clase de la sociedad, contribuyera económicamente a resolver las dificultades que atravesaba Hacienda, desgarrada tras la guerra de la Independencia, mediante un donativo ${ }^{6}$. No fue una novedad en ese año, pues el rey ya había recibido, desde el año anterior, otros

Diputación Permanente (1944). Su primera edición es de 1934.

Mosse (2000): 133 y Wasson (2006): 85.

6 Archivo General de Palacio (en adelante, AGP), Fernando VII, caj. 346, exp. 41 y caj. 323, exp. 1. Así lo comunicó el secretario de Hacienda a los duques, en nombre del monarca: «La memoria de los sucesos extraordinarios que en diferentes épocas han ocurrido en la Monarquía, y la reciente de las calamidades sufridas y superadas [...], han convencido al rey nuestro señor de que el celo y desprendimiento de esta primera clase del Estado, identificada con la existencia y esplendor del mismo, debe ser en las presentes circunstancias la que preste los recursos más eficaces para conservarlo, igualmente que los consuelos que necesita el corazón de S.M. penetrado del amago en que están los pueblos de sufrir nuevos gravámenes, cuando apenas respiran de los de la pasada desolación». A este último argumento también se aludió para justificar la aceptación del presupuesto que las Cortes de Cádiz habían legislado para la Real Casa, pese a la derogación de casi toda su obra legislativa. Y ello debe ponerse en relación con una nueva herramienta de legitimación política que Fernando VII activó durante su reinado: la aceptación popular. 
socorros económicos de sus súbditos, tanto a nivel particular como institucional, como cabildos eclesiásticos, diputaciones y ayuntamientos ${ }^{7}$. Pero era la primera vez que, en muchas décadas, la Corona convocaba a toda la grandeza.

Los fieles colaboradores del rey ${ }^{8}$ organizaron dos reuniones en Madrid, en las Casas Consistoriales, al mes siguiente. En la esquela de la primera convocatoria se señaló que las damas que tenían asiento por ser titulares o tutoras de sus hijos menores podían delegar sus funciones en otros grandes, como así ocurrió a petición inicial de algunas nobles 9 . De 121 grandes acudieron 62, y de los 28 honorarios se presentaron 6 en las primeras sesiones ${ }^{10}$. En esas Juntas Generales los presentes pudieron renovar su voto de fidelidad a la Corona, al tiempo que esta les solicitaba una cuota que fuera compatible con el mantenimiento de su posición social. El duque del Infantado aclaró que no se trataba de realizar un reparto ni de imponer un impuesto, sino de contribuir individualmente ${ }^{11}$. Cada título se comprometió a enviar su ayuda, según organizasen sus papeles y percibiesen sus rentas.

Concretamente, fue el 11 de junio de 1815, en la segunda Junta de la Grandeza cuando se concretó la ofrenda: 36 nobles ofrecieron al monarca la décima parte de sus rentas anuales; 13 prometieron dinero líquido que, en total, alcanzó la cifra de 627176 reales, y 18 hicieron promesas definidas o vagas para contribuir al donativo ${ }^{12}$. Al igual que los regalos de particulares y de instituciones, los grandes hicieron entrega de dinero, aunque también hubo ofrecimientos en especie, como el conde de Cervellón que entregó 2000 fanegas de trigo ${ }^{13}$. Igualmente, fue frecuente la oferta al monarca de sueldos

\section{La Parra (2018): 283-284.}

8 Lo eran desde antes de la guerra de la Independencia, como analiza La Parra (2010).

9 AGP, Fernando VII, caj. 347, exp. 3. La madre del conde de Parcent preguntó la forma de asistir y la duquesa de Medina de Rioseco escribió cediendo la representación a su marido, exento del Real Cuerpo de Guardias del Rey. AGP, Fernando VII, caj. 346, exp. 29. No quiere decir que no firmaran sus propias propuestas de donativos, como la condesa de Cifuentes que cedió un situado sobre los heredamientos del Real Sitio de Aranjuez que ascendía a unos 6.000 reales. Carta al duque de San Carlos, 15 de junio de 1815.

10 AGP, Fernando VII, caj. 346, exp. 30. Se ignoraba la residencia concreta de veintitrés grandes, algunos de ellos en el extranjero. De la primera sesión solo se conserva la lista de veintidós ausentes, sin señalar el total de asistentes.

11 AGP, Fernando VII, caj. 346, exp. 41. Con estas mismas palabras se invitó a sumarse al donativo a los grandes ausentes. Carta de Infantado a San Carlos, 9 de julio de 1815. AGP, Fernando VII, caj. 346, exp. 41.

12 AGP, Fernando VII, caj. 346, exp. 41.

13 AGP, Fernando VII, caj. 347, exp. 3. Carta del secretario de la Diputación, 13 de septiembre de 1815. Señala que el conde de Cervellón y su hijo el duque de 
atrasados y no percibidos (fue el caso, entre otros, del duque de Montemar, que cedió los 93300 reales que se le debían como gran canciller del Consejo de Hacienda y sus tribunales ${ }^{14}$ ) o títulos de deuda pública, como el conde de Colomera, que cedió 43410 reales de réditos por vales reales, deuda acumulada en los años previos a la invasión francesa ${ }^{15}$. Muchos aprovecharon la ocasión para recordar sus contribuciones - en dinero, especie o cesión de sueldos- a la regencia durante la guerra, además del desastroso efecto de la misma sobre sus economías ${ }^{16}$.

Se comunicó la resolución al rey y al secretario del despacho de Hacienda, aunque se condicionó la entrega de la ofrenda del primer y tercer grupo de nobles a los rendimientos de sus propiedades, muy malheridas, sin perjuicio del pago de contribuciones ordinarias. Como algunos grandes no habían concretado su aportación ni asistido a la reunión, la Diputación prometió que también comunicaría sus ofrecimientos más adelante. El tesorero general, una vez informado, solicitó inmediatamente la cifra de dinero ofertada, pero el secretario de la Junta — titular del señorío de Rubianes ${ }^{17}$ — le contestó que su cargo no le obligaba a recaudar las sumas ofrecidas, manifestando que no entendía su premura, la cual podía añadir serios problemas al esfuerzo que las debilitadas haciendas de los grandes realizaban. Se produjo un pequeño conflicto entre el tesorero y el señor de Rubianes, pues el primero escribió al secretario de Hacienda para que comunicara al rey el fracaso de su gestión. El malestar de Fernando VII debió motivar que los duques de San Carlos e Infantado solicitaran al secretario de la Junta que mejorara sus relaciones con el funcionario de Hacienda, a lo que tuvo que transigir con su mentalidad nobiliaria, acostumbrada a ceder los asuntos de dinero a sus propios administradores.

En las siguientes Juntas de la Grandeza, realizadas el 3 y el 10 de agosto, fueron elegidos por voto secreto los vocales de su Diputación Permanente: los

Alburquerque ampliaron su donativo al poco tiempo con la oferta de 702010 reales de vellón y 9 maravedíes que les reportaban sus sueldos atrasados como militares de alta graduación.

14 AGP, Fernando VII, caj. 347, exp. 3. Carta de 17 de agosto de 1815.

15 Señaló, por carta fechada el 12 de agosto de 1815, que los recibos originales, fechados entre 1800 y 1808, se habían perdido durante su huída de Málaga, cuando la ciudad fue tomada por las tropas napoleónicas. Añadió también tres mesadas de su sueldo como consejero de Estado, aún pendientes de cobro. AGP, Fernando VII, caj. 347, exp. 3.

16 Por ejemplo, el conde de Molina había cedido su sueldo de coronel a la regencia desde 1810, que ascendía a 144000 reales. AGP, Fernando VII, caj. 347, exp. 3.

17 Miguel Gayoso y Caamaño, señor de Rubianes, que contrajo matrimonio con María Josefa Villegas y Coronel en 1817, y que falleció el 13 de enero de 1826. 
duques de San Carlos ${ }^{18}$, Parque, Híjar, Villahermosa y Montemar, el conde de Miranda y, nuevamente como secretario, el señor de Rubianes. Cuatro días más tarde tuvieron su primera reunión —esta vez en el Palacio Real de Madrid-, donde acordaron que cada viernes se congregarían en casa del duque de San Carlos, señalando como primeras tareas una audiencia con el rey el día 18 de ese mes para trasmitirle las gracias por permitir que la grandeza eligiera una Diputación ${ }^{19}$; reunir toda la información posible sobre sus miembros para conocer el estado en que se hallaban exactamente; escribir una carta circular señalando los nombres de los vocales, el objeto de la Diputación y sus atribuciones, así como la cantidad que cada grande se había comprometido, el modo y manera en que tenían para comunicarse con la misma, dando los primeros pasos, igualmente, para nombrar un oficial mayor de la secretaría ${ }^{20}$. Todo ello demostró su voluntad para que la Junta no fuera un organismo meramente coyuntural, sino que tuviera una vocación de permanencia en el entramado político.

La recaudación del donativo se demostró lenta y pronto atravesó dificultades, pues el tesorero general continuó quejándose, al tiempo que la secretaría de la Diputación recibía numerosas protestas de grandes por las actuaciones del fisco, al lanzar contra ellos a pueblos y colonos en pleitos por la titularidad de los señoríos, lo que mermaba su capacidad económica. Algunos títulos solicitaron permiso para vender parte de sus bienes amayorazgados para poder cumplir con el donativo. Por esas fechas, al menos quince grandes no se encontraban viviendo en Madrid ni sirviendo en la corte, situándose al frente de sus haciendas en provincias, lo que demostraba su interés por reorganizar y asentar sus fuentes de riqueza tras la guerra ${ }^{21}$.

18 San Carlos, una vez nombrado embajador en Viena, fue reemplazado por el conde de Miranda, mayordomo mayor, de forma interina hasta la elección de su sucesor el marqués de Santa Cruz por sorteo.

19 Así se hizo, pues el infante don Antonio ordenó que se preparara la sala de damas de la reina madre para esta junta, con un retrato del rey bajo dosel, con la silla destinada al monarca, vuelta, una mesa, varias sillas regulares para los vocales y un sillón para el vicepresidente, dos sillas de bancos paralelas para los asistentes, dos para la votación y una escribanía. AGP, Fernando VII, caj. 346, exp. 41.

20 AGP, Fernando VII, caj. 347, exp. 3. Se imprimió un modelo de carta, que fue enviado a todos los grandes, comunicándoles estos hechos e invitándoles a definir mejor la forma de su aportación al donativo.

21 Por ejemplo, el conde de Revillagigedo que, si bien se comprometió a respaldar el acuerdo que tomara la Junta General, abandonó la capital por los gastos que su posición le obligaba, debido a su mala situación económica. Carta al duque de San Carlos,11 de junio de 1815. AGP, Fernando VII, caj. 347, exp. 3. 
Los diputados volvieron a reunirse el 19 de enero de 1816, bajo la presidencia del tío del monarca. El secretario expuso una síntesis de las actuaciones de la misma, que hasta ese momento habían alcanzado la cifra de 87 acuerdos, entre ellos la realización final de un catálogo general de todas las grandezas de España, con sus títulos, apellidos, poseedores, familia, lugar de residencia y apoderados, cuya copia ofreció al infante ${ }^{22}$. Informó que, si bien continuaban llegando ofrecimientos de algunos grandes, como el duque de Ciudad Rodrigo — duque de Wellington, residente en París—, que determinó su oferta de auxilio en la décima parte de sus rentas de un año, la percepción del donativo estaba cumpliéndose con dificultad, al recaudarse tan solo 5661 reales hasta ese momento desde que, en mayo del año anterior, el duque de Granada hubiera entregado 20000 a cuenta de su ofrecimiento ${ }^{23}$. No obstante, en la Junta General de la Grandeza de 11 de septiembre de 1816 el secretario expuso a los asistentes que, finalmente, el donativo había alcanzado la cifra de 7555370 reales de vellón, la mitad en metálico y el resto en aportaciones por donación en grano, suministros a las tropas, saldos, cesión de sueldos, pensiones, réditos, vales reales y derechos ${ }^{24}$. Esa cantidad casi igualaba a la que se presupuestaría en 1821 para los gastos de las Cortes y superaría la asignada a Ultramar. Pero como todavía había algunos grandes que no habían concretado su donativo o no lo habían satisfecho, los asistentes a esta última reunión acordaron volver a recordarles sus obligaciones, insistiendo en la medida y, en caso de que sus demandas fueran respondidas con el silencio, elevarlo al conocimiento del monarca.

Durante este primer sexenio del reinado de Fernando VII, la Corona distinguió a diversas personas con la grandeza ${ }^{25}$. La Diputación, al conocerlo, les solicitó su colaboración para el donativo, pues no era un asunto exclusivamente de viejos títulos. En los sucesivos meses fueron contestando algunos miembros de la grandeza, manifestándose tan solo uno —el marqués de Casa

22 Desde 1816, al detectarse varios errores importantes, se ordenó al impresor de la Guia de la Grandeza, que presentara, previamente a su impresión, el manuscrito a la secretaría de la Diputación Permanente, sin cuya autorización no podría editarse.

23 Carta del secretario de la Diputación, 5 de septiembre de 1815. AGP, Fernando VII, caj. 347, exp. 3. El decisivo papel de Wellington en la restauración del legitimismo monárquico fue aclarado por La Parra (2014).

24 Por ejemplo, la marquesa de Peñaflor cedió a favor de la Corona las alcabalas de la villa del mismo nombre, que ascendían a 14000 reales anuales, más una serie de potros útiles de su yeguada para el ejército. AGP, Fernando VII, caj. 347, exp. 3.

25 AGP, Fernando VII, caj. 346, exp. 38 y caj. 397, exp. 25. El rey concedió grandezas hasta su muerte, como al duque de Noblejas (1820), al vizconde de de Saint Priest (1830) o al general de la orden hospitalaria de San Juan de Dios (1833). 
Ferrandell desde Palma de Mallorca—imposibilitado para hacer ningún tipo de donativo, por razones económicas. A pesar de lo acordado, en la Junta General de 27 de marzo de 1817 todavía - y teóricamente por última vezse realizó una llamada a los ocho aristócratas que no habían abonado el donativo, a los cinco que no habían contestado y a los tres que solo habían abonado una parte de su donativo, comunicándoles que, además de un desaire contra la Corona, atentaba su actitud contra el resto de grandes. Cinco meses más tarde, el vocal secretario podía señalar, ante el resto de asistentes, que la cifra total del donativo hacia aumentado hasta 8454713 reales. Y para intentar convencer a los pocos que faltaban por cumplir se intentó atacar directamente su honor: el duque del Infantado propuso que se escribieran sus nombres en una lista, custodiada en un arca de tres llaves, para su vergüenza, lo cual fue apoyado por unanimidad en pública sesión ${ }^{26}$.

\section{SE INTENTA SU INSTITUCIONALIZACIÓN POLÍTICA}

El 10 de septiembre de 1815, la Diputación Permanente de la Grandeza decidió establecer un reglamento, formado por 43 artículos, que elevó a la aprobación del monarca ${ }^{27}$. Según el escrito, los nobles deseaban de esta manera apoyar, con sus vidas y haciendas, «los sagrados derechos del Trono de V. M.», renovando la promesa que le habían prestado en la iglesia de San Jerónimo al jurarle como príncipe de Asturias, de la cual jamás se habían separado durante la invasión francesa. Sus creadores trataron de concentrar la capacidad de comunicación de la grandeza con la Corona en esta institución, al señalar el artículo 24 que eran "el conducto para elevar al rey los asuntos de la clase», mientras que el 26 aclaraba que «la Diputación representa a toda la clase en general». Se regularon las capacidades del primer vocal, la organización de sus sesiones y las de la Junta General, una de las cuales, al menos, debía celebrarse anualmente cada 18 de agosto.

Fernando VII leyó el escrito y lo meditó, como demuestra el hecho de que tardara más de un mes en aprobarlo, pero finalmente lo aceptó, nombrando

26 Diputación Permanente (1944): 90-98.

27 Reglamento aprobado por el Rey Nuestro Señor D. Fernando VII para el régimen de la clase de grandes en sus Juntas Generales y las de su Diputación. En la Biblioteca Real se conservan dos ejemplares, uno impreso en 1815 en D. M. de Burgos y otro en mayo de 1833 en la imprenta de D. L. Amarita, sin ninguna variación salvo la firma final del secretario de la Diputación Permanente: el señor de Rubianes en el primero y el marqués de Miraflores en el segundo. 
a su tío, el infante don Antonio, como vicepresidente de las futuras reuniones de la Junta de Grandes, así como de su representación permanente ${ }^{28}$. Quizá estas últimas decisiones del rey demostraron que no pensaba otorgar demasiada importancia a la actuación de la misma, una vez conseguido el objetivo principal de lograr fondos para el maltrecho tesoro, misión principal para la cual se había formado también la Diputación. Así lo recordó, explícitamente y varias veces, el duque de San Carlos en su discurso ante el rey, en la audiencia a la Diputación celebrada el 18 de agosto de 1815. Por ello, aunque no parecía necesaria la creación de un reglamento tan extenso, finalmente accedió. Como se aprecia, esta iniciativa partió de algunos grandes que vieron una oportunidad para influir en el juego político de un régimen que concentraba, en grado superior a tiempos pasados, las decisiones en la Corona y sus ministros $^{29}$. Como había escrito el duque del Infantado al de San Carlos «el asunto es de importancia y si se realiza el proyecto creo será con el tiempo uno de los principales cimientos de la Monarquía, así como el mejor apoyo del Trono; y hará honor al rey que lo aprueba y al ministro que lo ejecuta $»^{30}$. Infantado siempre defendió un modelo de monarquía moderada, según el cual el rey habría de estar aconsejado por altos órganos integrados por miembros de la alta nobleza y las jerarquías eclesiásticas, representantes de los cuerpos intermedios del reino. No resulta extraño, por ello, su apoyo a la idea de una Diputación Permanente de la Grandeza.

El 6 de noviembre de 1815, el infante don Antonio resolvió que las Juntas Generales de la Grandeza, a partir de entonces, también se celebraran en una de las salas del Palacio Real ${ }^{31}$. El duque de Híjar y el señor de Rubianes elaboraron un minucioso reglamento para el ceremonial de recepción del rey o del infante que presidiera las Juntas Generales, tanto en palacio como en otra residencia, en la capital o en provincias, organizando la petición de palabra o la entrada en la Junta en caso de retraso de algún grande. Más adelante, el rey

28 AGP, Fernando VII, caj. 346, exp. 40. Se transmitió la aceptación del rey al secretario de la Diputación el 19 de octubre de 1815. A la muerte de su tío, el 20 de abril de 1817, Fernando VII nombró a su hermano el infante don Carlos para sustituirle.

29 El resultado fue una nueva política dominada por una fuerza, la cual, por el hecho de depender directamente del monarca, no tuvo otro límite que la voluntad regia. El rey pudo ejercer el poder con más libertad que sus predecesores, aunque siempre en continua tensión, no solo con quienes pretendían superar el sistema del Antiguo Régimen, sino también con los partidarios de volver al antiguo. La Parra (2018): 280-281.

30 AGP, Fernando VII, caj. 397, exp. 24. Carta de 20 de mayo de 1814. Sobre el pensamiento político de Infantado ver Carrasco (2006) y Alarcón $(2012,2015)$.

31 AGP, Fernando VII, caj. 346, exp. 37. 
concedió que, bajo presidencia de un infante, la Diputación tuviera la consideración y tratamiento protocolario de alteza y, cuando no acudiera, de excelencia $^{32}$. Aunque estos asuntos pudieran parecer baladíes no lo eran en absoluto: la etiqueta fue un medio de comunicación propio de la política cortesana que transparentaba el favor o la cercanía del monarca, ejerciendo una función simbólica de gran importancia. Los actos diarios del soberano adquirían un carácter de privilegio que distinguía a unas personas sobre otras, por lo que no resulta extraño que el monarca eligiera a quien consideraba más fiel para ocupar un alto cargo palatino que tenía fácil acceso a su presencia. Además, sus actos servían como indicador de la posición del individuo dentro del equilibrio de poder de las elites que le rodeaban, indicando su rango y dignidad. De ahí el cuidado que tenían incluso los políticos por su estricta ejecución, de tal manera que así pueden entenderse las protestas por incumplimiento de la etiqueta de altos funcionarios ${ }^{33}$.

El 11 de septiembre de 1816 se sortearon los reemplazos de dos vocales, siendo elegidos el conde de Fuentes y el marqués de Cerralbo, que asumió la secretaría por unanimidad. A esa Junta concurrieron 29 grandes con 37 representaciones, siendo el censo cercano a la centena. Por esas fechas, dando muestras de un inusitado interés, la Diputación se había reunido en 46 ocasiones, había elegido un oficial de secretaría y pronto también crearía una plaza de agente. Se acordó informar de algunos asuntos — tratados en la Junta General- al ministro de Estado para que fueran publicados en la Gaceta, muestra todo ello de la voluntad de sus dirigentes por funcionar de acuerdo con su propia reglamentación, al tiempo que trataban de institucionalizarse en el entramado administrativo y político ${ }^{34}$. Para dignificar todavía más a sus dos empleados, un año más tarde solicitaron a Fernando VII que les concediera el título honorífico de "secretarios del rey»"

En la Junta General de 18 de agosto de 1817 fueron elegidos nuevos vocales - el duque de Frías y el conde de Altamira- junto al duque del Parque, el de Híjar, señor de Rubianes, conde de Fuentes y el marqués de Cerralbo. En el otoño el rey aceptó su propuesta, por la cual su mayordomo mayor y todos los que le sucediesen formarían parte de la Diputación ${ }^{36}$, elevándose así a siete el número de sus miembros. Tras el fallecimiento de

32 Real Decreto de 20 de marzo de 1816.

33 Así se comprueba en Moral (2018): 163-166.

34 Los gastos de administración y personal fueron asumidos por los grandes mediante un sistema de derramas y cuotas.

35 Diputación Permanente (1944): 99.

36 Petición fechada el 11 de septiembre de 1817. AGP, Fernando VII, caj. 346, exp. 39. 
Híjar, a finales de 1817, fue elegido vocal el conde de Salvatierra. A mediados del siguiente año se eligieron dos vocales por renovación, el duque de Medinaceli y el de San Fernando, y como segundo secretario al conde de Bornos. Varios nobles intentaron excusarse para no asistir como vocales, como el duque de Castroterreńo o el marqués de Villafranca, amparándose este en su empleo como caballerizo mayor de la reina. Sin embargo, la Diputación se mantuvo inflexible, no aceptando ninguna justificación.

Hasta 1820, numerosos grandes elevaron solicitudes de justicia a la Secretaría de la Diputación por varios asuntos de carácter individual — generalmente por atropello de sus haciendas e intereses económicos-, solicitando su apoyo para defender su causa ante el rey. La inmensa mayoría fueron devueltas a sus autores, recomendándoles que acudieran personalmente a los tribunales en la forma y lugar que mejor estimaran. Y es que la Diputación siempre intentó primar los asuntos de carácter general que afectaban a la grandeza en su conjunto, como clase distinguida. Así, no dudaron en elevar al monarca la relación de los importantes auxilios que habían realizado el conde de Maceda y el marqués de Camarasa para derrotar el pronunciamiento del general Juan Díaz Porlier, entre el 19 y el 11 de septiembre de 1815, en Galicia. Pues, con sus acciones, se demostraba que eran «innumerables, Señor, los ejemplares que atestiguan la fidelidad y amor de la Grandeza a sus soberanos, y para mayor conocimiento de la fidelidad de esta primera clase del Estado, y que jamás faltará a sus deberes» ${ }^{37}$.

\section{DEFENSA DE LA DISTINCIÓN}

Ciertos grandes aprovecharon el nuevo foro de las Juntas Generales y de la Diputación para, a través de sus propuestas y discursos, reafirmar su identidad, revalorizar ante el monarca sus acciones, justificar sus privilegios y perpetuar su distinción, que justificaba su participación política. En la vecina Francia, desde la Revolución, había surgido una nueva nobleza que no se basaba en la sangre — según la concepción tradicional—, sino en el dinero y el mérito personal, que debían demostrar a la sociedad, como han subrayado Daumard y Tudesq ${ }^{38}$. Luis XVIII había integrado los títulos concedidos por la dinastía Bonaparte con la vieja nobleza y, a partir de entonces, dignidad y

37 AGP, Fernando VII, caj. 346, exp. 37. Madrid, 10 de octubre de 1815. Nueve días más tarde, el rey mandaba a la Diputación que trasladara su agradecimiento a los dos nobles.

38 Daumard (1988): 81-86 y Tudesq (1988): 121-122. 
fortuna fueron los fundamentos de la aristocracia gala. La grandeza española debió sentir esos cambios, ya que comenzaron a demostrar — con este tipo de maniobras- que la genealogía y la sangre no bastaban para perpetuarse.

El duque de Villahermosa elevó a la Diputación una propuesta sobre si convendría solicitar al rey que declarara que los titulares de dos o más grandezas debían dividirlas entre sus herederos, el 19 de diciembre de 1816. Sus vocales se mostraron a favor, pues la reunión de grandezas disminuía el número de los miembros de su clase, que otorgaban esplendor a la Corona y dignidad al Estado; asimismo, cuanto mejor estuviera repartida la riqueza y mayor fuera el número de propietarios, aumentaría la prosperidad. De esta manera, solicitaron al duque de Villahermosa que formalizara mejor la propuesta que había elevado a su consideración y un plan para ejecutarla.

El duque de Parque, en la Junta General celebrada el 26 de marzo de 1817, apoyó la idea del duque de Villahermosa para evitar el abuso de concentración de grandezas en una sola persona, argumentando la futura desaparición de este grupo social, teniendo en cuenta la tendencia acumulativa pero también el número de familias que ya habían desaparecido. Se debía, en consecuencia, facilitar el reparto de grandezas para mejora de la clase, además de contribuir a prosperar su imagen ante la opinión pública, «circunstancia que nunca debe ser indiferente a la Grandeza $"{ }^{39}$. Dicha distribución se realizaría a partir del fallecimiento de los actuales poseedores y, al ponerse en votación si debía formarse un plan de acuerdo con esta propuesta, el resultado fue de apoyo mayoritario de los presentes (37 votos contra 5). Esta inquietud contrastó con la de la nobleza de los territorios sudoccidentales de Alemania, partidaria de limitar la extensión de sus familias, concentrando en el hijo mayor el título - como se realizaba en Inglaterra-, aunque las noblezas francesa y prusiana admitían el reparto de títulos entre los hijos varones legítimos ${ }^{40}$.

Además de estas iniciativas, los discursos de los grandes resultaron sintomáticos de sus aspiraciones políticas y sociales. En Junta General, celebrada el 11 de septiembre de 1816, el duque del Parque, vocal de la Diputación, realizó un discurso que aprovechó para describir y defender la conducta de la grandeza durante la ocupación francesa. Señaló que — pese a los intentos de destruirla por parte del hermano de Napoleón- José I había intentado

39 Archivo Histórico de la Nobleza (en adelante, AHN), Bornos, caj. 537, doc. 14. Memorial elevado al rey por la Diputación de la Grandeza, para que se rectifique la Ley que permite la agregación o unión de Casas Grandes en una misma persona, 19 de febrero de 1817.

Mosse (2000): 146. 
obtener su apoyo mediante prebendas y halagos, al reflexionar sobre las ventajas que conllevaría su apoyo. Parque adujo que estas fueron rechazadas por la inmensa mayoría de la nobleza española, que prefirió todo tipo de riesgos y privaciones antes que desmentir su lealtad. Ello — señaló el duquela hizo en cierto modo superior a sus antepasados, «no presentando la historia una época en que éstos hubiesen efectuado simultáneamente y con tanto desinterés igual suma de esfuerzos y merecimientos».

A continuación, el secretario de la Diputación, en su discurso definió a los grandes como "conservadores y guardianes del honor, alma de la Monarquía», al estar su existencia ligada con el poseedor del trono. A diferencia de los señores de otras naciones, la alta nobleza española había sabido actuar sin insolencia, sin la codicia que afecta a las haciendas públicas, sin bajeza ni altivez, sin tiranizar las provincias. Sus privilegios eran obra de la sabiduría y de la previsión, siendo claramente — por su virtud y beneficencia - depositarios del honor. Para el señor de Rubianes, la constitución de las Juntas y de la Diputación había supuesto una nueva fase en la historia de la nobleza, al dejar de estar limitada a las gestiones de servidumbre y etiqueta palatina. De esta manera, gracias al apoyo del monarca a su «nueva existencia y unión» los pueblos encontrarían en esta corporación a los mejores corresponsales en Madrid de los cuerpos patrióticos, a las personas necesarias en las Juntas de Caridad y Beneficencia, en la inspección de obras públicas, a los modelos de virtud y honor militar ${ }^{41}$.

En la disertación que realizó el secretario el 28 de junio de 1817, en Junta de la Diputación presidida por el infante don Carlos, se resumió la actuación de la misma, como era costumbre. Sin embargo, sus últimas palabras resultaron significativas: «la Grandeza cree haber correspondido a la Real merced: erigiéndole en cuerpo y dándole una existencia política mirada con prevención por sus émulos» por el apoyo que prestaba a la monarquía y «el respeto y amor que profesamos a Nuestro Soberano».

Nuevamente, el duque del Parque, en la Junta General de 18 de agosto, dirigió una exhortación a los grandes y a la nobleza en general, animándola a seguir el ejemplo de sus homólogas británica y francesa, trasladándose a vivir varios meses al año a sus posesiones en provincias, mejorándolas y ayudando a los pueblos con su presencia. Rubianes, ese mismo día, subrayó que el rey, al concederles esta corporación, les había otorgado un derecho político que la grandeza había sabido emplear para el bien común, no para sus propios

41 «Noticia de lo ocurrido en la Junta General de la Grandeza, convocada por disposición del Rey nuestro Señor, su presidente, en el día 11 del pasado», Gaceta de Madrid núm. 126, 10 de octubre de 1816, pp. 1109-1113. Sobre la presencia de grandes en las citadas sociedades ver Moral (2001). 
intereses. Así lo demostraba aludiendo a su postura anteponiendo siempre los derechos del monarca y la prosperidad nacional, tendiendo sus reclamaciones siempre a favorecer la paz social ${ }^{42}$.

Por su parte, en su discurso de 28 de noviembre de ese mismo año, el señor de Rubianes recordó el apoyo que la grandeza había otorgado a los monarcas medievales, concluyendo que la nobleza hereditaria era la historia de España, una jerarquía fundamental y una constante emulación para las demás clases sociales. Y es que la nobleza europea estaba demostrando su utilidad en el campo político como en estos discursos, ya que toda jerarquía social es una construcción histórica, y por ello capaz de ser reconstruida ${ }^{43}$. Rubianes reconoció su falta de educación - por otra parte, común al resto de las sociedad-, cuya consecuencia era la ausencia de buena administración de las rentas de algunos de sus individuos, de sus testamentarías y pleitos. Dibujó un panorama donde acreedores, abogados y jueces perjudicaban con sus dilaciones a la nobleza, por lo que terminó su discurso solicitando al rey que pusiera fin a tanto desorden, "separando el poder judicial del gubernativo" ${ }^{44}$.

La respuesta de la Corona fue de agradecimiento a su fidelidad y mantenimiento de su distinción social, pero nada más. No se legisló a favor de un reparto obligatorio de grandezas entre los herederos y poco se avanzó en los intentos de la grandeza por definir una participación especial en el organigrama político fernandino, así como en otros asuntos relacionados con la nobleza: sus señoríos y sus impuestos.

\section{UN PROBLEMA NOBILIARIO: LA INDEFINICIÓN DE LA CUESTIÓN SEÑORIAL}

La Diputación encomendó al duque de Híjar el escrito de la representación que habría de elevarse al rey sobre la situación de los derechos territoriales y representaciones de la nobleza — no solo de la Grandeza — ante «seis años de arbitrariedad e insubordinación». Se trataba de una cuestión de máximo interés político para este grupo social. El origen de sus quejas se encontraba en el Decreto de las Cortes de 6 de agosto de 1811 sobre supresión de señoríos ${ }^{45}$,

42 «Noticia de lo ocurrido en la Junta General de la Grandeza convocada en el día 18 de Agosto último», Gaceta de Madrid, núm. 122, 11 de octubre de 1817, pp. 1091-1094.

43 Powis (2007): 134.

44 Diputación Permanente (1944): 56-88.

45 Dicha legislación diferenció entre señorío jurisdiccional y señorío territorial o solariego, siendo susceptible el primero de incorporación o abolición, mientras que el 
al que el monarca había puesto límites por su Real Orden de 15 de septiembre de 1814, por la cual suspendía su ejecución, reintegraba y restituía aquello que no fuera notoriamente procedente de jurisdicción, reservándose la Corona su decisión respecto al futuro de los señoríos ya disueltos, tras conocer la resolución del Consejo de Castilla. Veinte días antes, un real decreto había otorgado a los ayuntamientos la capacidad de proponer una terna para cada uno de los oficios municipales, dejando a cargo de las Audiencias la designación en los lugares de señorío.

Según Híjar, la regia resolución — que debía haber sido interpretada como una derogación de la normativa gaditana- había producido el efecto contrario, al solicitar pueblos y colonos los títulos de propiedad a los nobles, negándose al pago de impuestos y rentas, creyéndose libre de jurisdicciones señoriales. Cada cobranza suponía para las haciendas nobiliarias el pago de un pleito, al tratar de confundir señorío territorial con señorío jurisdiccional, lo que provocaba gastos y retrasos en los abonos. Recordó que las prestaciones solariegas eran modificaciones del derecho enfitéutico, que nunca podía considerarse jurisdiccional; que la posesión no interrumpida era el mejor derecho de propiedad y que, en caso de duda, el juez era el único que podía solicitar una prueba documental. Al requerir el deudor el título de propiedad al noble, aquel se convertía en juez y parte, negándose al pago de la prestación. Como se señalaría en otros memoriales, los títulos de propiedad de la nobleza habían sufrido el paso de las guerras en los cuatro últimos siglos y muchos de ellos habían desaparecido con la quema de archivos y edificios.

El duque de Híjar denunció en su escrito, señalando algunos ejemplos, la situación actual que se resumía en que, si bien para no pagar contribuciones a la Corona los pueblos se amparaban en sus señores, inmediatamente dejaban de ser reconocidos cuando se les requería el pago de prestaciones ${ }^{46}$. Por ello, firmando este documento todos sus vocales el 21 de diciembre de 1815, la Diputación Permanente solicitó al monarca que se practicara la ley — pues su tergiversación alteraba el orden social—y que mandara cumplir a los pueblos, renteros y colonos:

segundo fue considerado propiedad privada. A partir de esos momentos, el problema no solo fue delimitar la naturaleza de los señoríos, sino la de los diferentes derechos componentes de la renta señorial. García Monerris (2002): 645-646. La importancia de las rentas agrarias en la vida nobiliaria del siglo xix está demostrada en los análisis de Sánchez Marroyo (2014, 2015); la desvinculación es analizada por Hernández Montalbán (1999) y Rueda Herranz $(1997,2014)$.

46 Lo mismo ocurría en otras partes de Europa, como señala Powis (2007): 125. 
Los pactos, condiciones y contratos a que se hubieren obligado por cualesquiera título, sin oponer dificultad alguna a no estar expresamente mencionada en el Real Decreto, sin que a pretexto de exigir documentos puedan negarse a este pago a que son obligados por solo la existencia del convenio, y que si tuviesen que demandar no pueden retener, ni dejar de contribuir mientras que por tribunal competente no se declare insuficiente el título de perceptor, único medio para evitar el cúmulo de males que todo propietario experimenta ${ }^{47}$.

Fernando VII, como consecuencia de esta representación, solicitó consulta al Consejo de Castilla, pero el tiempo transcurrió sin que se resolviese, por lo que la Diputación acordó y elevó nuevamente al rey, el 30 de abril de 1816, la petición sobre señoríos, escudándose tanto en la defensa de la propiedad y de la seguridad como en la necesidad de que las órdenes del rey se cumplieran, puesto que afectaban a su imagen y poder. Manifestaron que continuaban llegándoles noticias y quejas de numerosos grandes - entre ellos, los marqueses de Mos y Castelar, el conde de Altamira y el duque de Alba_ ${ }^{48}$ al respecto. Sus vocales solicitaron una pronta resolución al monarca, presentándole un paisaje de desdichas nobiliarias, ataques a la propiedad, casas invadidas, administradores asesinados, sacerdotes atormentados, juntas populares no autorizadas, ataques al orden social y una amenaza de guerra civil entre pobres y propietarios, especialmente en Galicia y Valencia. Por ello, requirieron al monarca que ordenara a su Consejo que emitiera pronto su dictamen y que se cumpliera, por parte de las autoridades, el Real Decreto de 15 de septiembre, volviendo las jurisdicciones y la facultad de nombrar jueces a aquellos que anteriormente la poseían.

Cuando llegó, finalmente, la respuesta del Consejo de Castilla fue una decepción: al no obtener resultado de sus peticiones a la Secretaría de Gracia y Justicia sobre antecedentes de las Cortes, sus fiscales apelaron a la socorrida medida dilatoria de solicitar el desglose de varias piezas del expediente sobre señoríos. Al conocerse la resolución en una reunión de la Diputación, sus vocales censuraron ante el monarca tan lento procedimiento, al no haber

\footnotetext{
Diputación (1944): 51.

48 Numerosos de estos títulos pertenecían a la grandeza proveniente de Castilla, pero que tenía un importante patrimonio en el reino de Valencia. Compuesto fundamentalmente por rentas jurisdiccionales enajenadas a la Corona y a los municipios, además de derechos territoriales, se encontraban por entonces en una crítica situación, como ya demostró Ruiz Torres (1988). Como tradicionalmente habían tenido una fuerte influencia en la corte, intentaron utilizarla en esos momentos también para defender su patrimonio.
} 
contestado a su pregunta sobre si los nobles debían volver al goce de sus señoríos, ilegalmente desposeídos por las Cortes, o si convenía que el rey declarase totalmente abolidos los señoríos jurisdiccionales, pues había títulos que todavía mantenían jueces gratuitamente, sin posibilidad de cobro. En los meses siguientes, los vocales de la Diputación trabajaron reuniendo información y dictámenes para elaborar, entre todos, un documento de respuesta.

El 2 de noviembre, en presencia del infante don Antonio, el vocal secretario volvió a insistir sobre la negativa situación económica generada por la abolición de los señoríos jurisdiccionales y los continuos ataques contra la nobleza, «al parecer sostenidas por los Tribunales y Ministerios». Solo cabían dos soluciones: o favorecer a los señores o perjudicarlos. En el primer caso, los pueblos elevarían un aluvión de recursos legales para excusarse, no descartándose respuestas más violentas. En el segundo, su osadía y arrogancia no tendría limites a partir de ahora, por lo que resultaba necesario — en opinión de la Diputación- buscar una solución para conciliar a pueblos y nobles. Por ello, requirieron una mayor presencia de grandes —elegidos por el infante, es decir, por el rey en última instancia - en la resolución de esta espinosa cuestión de los señoríos.

El 6 de marzo de 1817, la Diputación elevó otra protesta a Fernando VII por la exigencia de presentación de títulos de propiedad antes del plazo de prueba; por los secuestros de bienes en caso de no presentación de documentos, como si los nobles fuesen delincuentes; por el procedimiento utilizado en las reversiones, incorporaciones y tanteos que perjudicaban a los títulos frente a los reclamantes, a los que presentaron llenos de malicia, ambición y espíritu de venganza. En definitiva, plenos de odio a la nobleza, aunque no precisaran tanto. Solicitaron que se cumpliera la ley — no que se variara—, que el demandante no tuviera ninguna renta anterior retrasada en pago, ya que eran antiguos arrendatarios y colonos los que pleiteaban, abonando a plena satisfacción del noble la indemnización estipulada. Asimismo, denunciaron que las tasaciones no tenían en cuenta ni las mejoras realizadas ni la variación del valor de la moneda, por lo que lo justo era que se estimaran las fincas con un valor actualizado. Criticaron cuanto pudieron la actuación del Ministerio de Hacienda, encargado de estos asuntos, frente al desempeńo anterior del Consejo de Castilla, que había actuado, en su opinión, de mejor forma.

Dos meses más tarde, la indignación de los vocales volvió a desatarse al leerse la providencia del Consejo de Hacienda, basada en un nuevo informe de sus fiscales, fechado el 6 de mayo, donde tornaron a reclamar papeles y antecedentes, tanto de las Cortes de Cádiz como de épocas posteriores, sin llegar a ninguna conclusión. Los grandes protestaron ante el rey por este escrito, que otorgaba mayor importancia y equidad a los diputados gaditanos que al Consejo de Castilla o a la Secretaría de Gracia y Justicia. Denunciaron 
que en los antiguos señoríos jurisdiccionales reinaba el caos y la injusticia, ya que los nuevos magistrados nombrados por audiencias y chancillerías, al comprobar que no cobraban los antiguos sueldos que pagaban los señores, devolvían los empleos, mientras otros - con la complicidad de escribanoscorrompían los procesos para ganar dinero, en perjuicio de jornaleros y propietarios. Volvieron a solicitar un dictamen definitivo, elevando el tono de sus palabras, al señalar que el rey no había necesitado ninguna consulta para reponer el Concejo de la Mesta, el voto de Santiago, el Consejo de Castilla, así como las propiedades y regalías arrebatadas al clero. Le recordaron que, si se restauraban los señoríos jurisdiccionales, la Hacienda Real ahorraría sueldos de funcionarios judiciales y la nobleza podría tener rentas suficientes para pagar sus impuestos, lanzas y medias anatas.

Pronto se supo que dicha providencia se iba a cumplir, dilatando todavía más el proceso, por lo que los vocales intentaron frenarla por todos los medios posibles. Los condes de Miranda y de Fuentes pidieron al ministro de Gracia y Justicia su suspensión, visitándole en dos ocasiones, pero, al no quedar satisfechos de sus palabras, solicitaron audiencia al infante don Carlos que, a continuación, se entrevistó con su hermano. Su intervención debió ser decisiva, pues Fernando VII reaccionó suspendiendo la providencia del Consejo de Hacienda, al que ordenó que le facilitara con la mayor urgencia posible un dictamen definitivo, lo cual comunicó a la Diputación de la Grandeza a finales de junio. Todo ello demuestra que el sistema político imperante había mermado el poder de los consejos, aumentado el de los ministerios y, sobre todo, concentrado la última decisión en la Corona.

Al poco tiempo se supo que de los tres fiscales encargados del asunto tan solo uno era partidario de reintegrar los señoríos. Los otros continuaron siendo partidarios de reunir más información, consultando a chancillerías y audiencias, y conservar el decreto de 1814 ante el escándalo de los grandes que vieron en ello el mantenimiento de la situación que denunciaban hasta que llegara el momento para legalizar totalmente su desaparición. La Diputación decidió continuar presionando al rey, pero — para dotar de fuerza a sus demandas - enviaron un cuestionario a los grandes para que señalaran las cantidades que se gastaban en la Administración de justicia, seguridad de prisiones y mantenimiento del orden en sus señoríos. De esta manera pretendieron reforzar sus argumentos, aunque el agente de la Diputación aconsejó a sus superiores que esa vía resultaría, por su naturaleza, lenta, de exactitud relativa y, por ello, de escasa solidez. Mejor, en su opinión, sería convencer personalmente al rey para que resolviera sin más dilación ni espera ${ }^{49}$. Paralelamente,

49 Diputación Permanente (1944): 101. 
algunos nobles a la hora de definir su donativo al rey — como ya se ha hecho alusión- lo ligaron al producto de las rentas de sus señoríos, con la esperanza de que el monarca se convenciera de la necesidad de restituirlos ${ }^{50}$.

La dilación se mantuvo durante los siguientes ańos por parte del Ministerio de Hacienda, de tal manera que el agente de la Diputación informó, en una ocasión, a sus vocales que en el consejo pleno del mismo lo habitual era que sus componentes solo centraran su atención en expedientes de otras temáticas, como la extracción de granos. Quizá por ello, la grandeza solicitó la intervención del infante don Carlos para que el asunto de los señoríos fuera trasladado al Consejo de Estado, al cual el rey había otorgado mayor importancia política en esos años. En la Junta de 13 de marzo de 1818 se volvió a rogar al infante su apoyo para que el asunto pasara del Consejo de Hacienda al de Castilla, para su pronta resolución. En las siguientes se le informó de las protestas de la nobleza del reino de Valencia, quejosa de la actuación del intendente y de la Junta del Real Patrimonio, que calificaron de persecutoria. A cualquier vasallo se le reconocía el derecho de prescripción al cabo de veinte o treinta años de posesión, pero no así a los grandes. Argumentaron, recurriendo a sucesos y donaciones de la Edad Media, que las tierras de la nobleza valenciana nunca habían sido de realengo y así se habían reconocido hasta vísperas de la guerra de la Independencia.

Finalmente, todas sus maniobras se revelaron infructuosas y el 25 de noviembre de 1819 Fernando VII firmó un decreto que supuso la definitiva liquidación de los aspectos jurisdiccionales del señorío, al reservarse la Corona la designación de los oficios de regidores, procuradores y otros que antes proveían los señores jurisdiccionales. No resulta extraño que cinco días más tarde la Diputación solicitara al duque de San Fernando, secretario de Estado, su parecer sobre un informe que su asesor había escrito sobre sus fueros y preeminencias, puesto que sus vocales solo aspiraban a "tener una noción exacta» de los que no habían sido derogados todavía ${ }^{51}$. El protagonismo de la Corona

50 Tal fue el caso del conde de Torralba y Tabera, consorte de la duquesa viuda de Medina de Rioseco, que elevó petición a la Diputación —en septiembre de 1817_ para que el monarca determinara los adeudos de renteros de las propiedades de su tercera esposa, cuyas cantidades había cedido como donativo. En 15 de julio de 1815 seńalaron que habían cedido durante la guerra de la Independencia a las arcas reales 114122 reales y 4628 tárragas de grano. Ofrecieron a continuación 2292 fanegas de todos los granos y unos 15000 reales de los adeudos de sus colonos. Ese mismo año, el marqués de Velliscas había ofrecido 23000 reales que le debía la villa de Onteniente por rentas atrasadas anteriores a 1808. AGP, Fernando VII, caj. 347, exp. 3.

51 Diputación Permanente (1944): 132. Al año siguiente, solicitaron un informe sobre los privilegios de los grandes reconocidos en otros reinos europeos. 
y de sus ministros fue decisiva, pues, en la abolición del régimen señorial, lo cual — unido a otros hechos — desmonta la famosa alianza nobleza-burguesia liberal contra los campesinos ${ }^{52}$.

\section{VALES, LANZAS Y MEDIAS ANATAS}

En la reunión celebrada el 8 de febrero de 1816 se valoraron las peticiones de varios vocales para que se acreditara el papel moneda de forma urgente, por lo que se formó un plan sobre la redención de censos en vales reales, estableciendo la alternativa de redimir en fincas los réditos de los capitales invertidos, sin olvidar las compensaciones que pudiera realizar el crédito público. Con la intención de elevar el valor de los vales, solicitaron al rey el día 22 que las pragmáticas sanciones promulgadas por Carlos IV sobre los mismos fueran cumplidas. Paralelamente, se propuso que todo empleado o agraciado con una merced regia, antes de obtener su despacho, presentara una determinada cantidad de vales, como donativo extraordinario, para ser amortizados. Formularon que, con la garantía del crédito público, se facilitara la redención de censos al 2-3\% de interés por vales reales al $4 \%$. Asimismo, que el pago de lanzas (impuesto propio de la nobleza) y medias anatas se pudiera realizar - durante un quinquenio o sexenio- mediante vales reales, en vez de numerario $^{53}$. Estas medidas beneficiarían a la aristocracia en general, la cual poseía deuda pública y debía atrasos a la Corona por sus impuestos desde hacía décadas, ya que la media anata se abonaba al heredar una merced nobiliaria y al jurar cualquier cargo de la administración, muchos de los cuales se encontraban ejercidos por títulos e hidalgos.

52 Además de que los pueblos consiguieran rebajas de renta, perdón de atrasos y dilación de abonos, como ya señaló en su estudio Carmona (2001), para el caso de la Casa de Alcañices.

53 En 1787 se estableció que los que poseyeran grandezas y títulos de Castilla y no estuvieren relevados del servicio de lanzas ni las tuvieren consignadas en juros o en bienes libres, debían consignar alguna finca del mayorazgo a que se hubiese agregado la grandeza o título y rindiera la renta equivalente, para que quedase satisfecha anualmente la Real Hacienda, prohibiéndose la expedición de cartas de sucesión mientras no se acreditase haberse hecho la consignación para el pago del impuesto. No obstante, muchos nobles continuaron ligando el impuesto a la deuda pública bajo el reinado de Carlos IV. Lanzas y medias anatas estuvieron vigentes hasta la reforma del sistema tributario en 1845, cuando se creó el nuevo impuesto especial sobre grandezas y títulos, regulado por el Real Decreto de 28 de diciembre de 1846. Ver Sanz Ayán (2011) y Barrios Pintado (2016). 
Algo propio de la alta nobleza era, precisamente, la media anata y lanzas que abonaban al cubrirse, por primera vez ante el rey, lo que se concretaba en una ceremonia llamada la cobertura de los grandes. En una época en que el debate político europeo había puesto en claro entredicho los privilegios jurídicos de la nobleza —o al menos, algunos de los más importantes - la cobertura se consideró una de sus principales prerrogativas y una manera de demostrar socialmente la dignidad de la aristocracia ${ }^{54}$. Cubrirse ante el monarca se consideraba un privilegio que era necesario en caso de aspirar a una serie de cargos en el organigrama de la corte. Por otra parte, era claramente una obligación propia de su dignidad, aunque, paradójicamente, no resultaba obligatorio hacerlo en un plazo determinado. La elección de la fecha era arbitraria: el grande solicitaba realizar la ceremonia y, si cumplía las condiciones necesarias, la mayordomía mayor del rey le comunicaba una fecha.

TABLA 1. Cobertura de grandes (junio de 1814-agosto de 1820)

\begin{tabular}{ccccc}
\hline Año & $\begin{array}{c}\text { Grandes } \\
\text { de } 1 .{ }^{a} \text { clase }\end{array}$ & $\begin{array}{c}\text { Grandes } \\
\text { de } 2 .{ }^{a} \text { clase }\end{array}$ & $\begin{array}{c}\text { Solicitan exención } \\
\text { de gastos }\end{array}$ & $\begin{array}{c}\text { Se concede } \\
\text { la exención }\end{array}$ \\
\hline 1814 & 21 & 6 & 3 & 2 \\
\hline 1815 & - & 2 & 2 & 1 \\
\hline 1816 & 1 & 2 & - & - \\
\hline 1817 & 3 & - & - & - \\
\hline 1818 & 1 & - & 1 & - \\
\hline 1819 & 2 & 1 & - & - \\
\hline 1820 & 5 & - & & -
\end{tabular}

Fuente: AGP, Fernando VII, caj. 398; caja 73, exp.3 y Libro registro 4945.

54 Tanto que algunos grandes, residentes en el extranjero, intentaron conseguir permiso del rey para cubrirse ante un miembro de la realeza europea. Tal fue el caso del duque de Terranova y Monteleón, residente en Nápoles, que lo solicitó para cubrirse ante el duque de Calabria o el rey de las Dos Sicilias. El rey aceptó, pues su abuelo Carlos III había concedido igual permiso a sus antepasados. AGP, Fernando VII, caj. 397, exp. 29. En el siglo xIx la nobleza europea aceptó la sangre, el mérito demostrado, la dignidad y el dinero como elementos definitorios, como se aprecia en Wasson (2006), Tudesq (1988) y Beckett (1988). La ceremonia del cubrimiento perduró en España hasta 1931. 
Algunos grandes solicitaron la exención de gastos, es decir, de impuestos, al monarca, debido a su mala situación económica, prometiendo — en ciertos casos- que abonarían los mismos cuando pudieran. Fernando VII accedió a algunas de esas peticiones, aunque señaló que esas circunstancias no debían servir de ejemplo ni de imitación ${ }^{55}$. Hubo quien recordó que la dispensa de pago había sido unida a la concesión de la citada dignidad a uno de sus antepasados, lo cual — si se comprobaba documentalmente- se respetaba. Los datos expuestos en la tabla 1 revelan que la mayoría de grandes abonó los impuestos, y fue el año de la vuelta de Fernando VII de su cautiverio en Francia una ocasión que aprovecharon veintiséis grandes para cubrirse y, de esa manera, demostrar también la legitimidad política del monarca, ya que no lo habían hecho ante el hermano de Napoleón por ser un usurpador, un rey ilegítimo ${ }^{56}$. Precisamente, se denegó la solicitud de cubrimiento del marqués de Monreal y Santiago «por haber tenido la llamada cruz de la Orden Real de Españas ${ }^{7}$.

La petición de 1816 concluía señalando que si el rey aprobaba las propuestas de la Diputación —en opinión de los grandes— se revalorizarían los vales, se recogerían un importante número de los mismos, reduciéndose el pago de sus réditos, aumentando su capital y consolidando la imagen del monarca como restaurador del crédito público, en calidad de ser el primer voluntario en hacer cesiones y sacrificios. Los grandes fueron realistas: en ningún caso pudieron solicitar la abolición de estos impuestos pues desde mediados del siglo XVIII la Corona había legislado para que no se pudiera redimir el pago de lanzas y medias anatas por ningún medio, ya que deseaba conservar perpetuamente esos impuestos como renta fija.

Para el abono de las obligaciones y créditos de la hacienda, los vocales de la grandeza aconsejaron que no se variara la legislación establecida, respetándose así escrupulosamente las propiedades que las sostenían. Y, finalmente, señalaron al soberano que, en su opinión, las causas del descrédito público se encontraban en la expatriación de numerario tanto por la emigración de afrancesados y por el contrabando, así como por la compra de bienes al extranjero, consecuencia del estado de ruina provocado por la invasión francesa.

55 AGP, Fernando VII, caj. 398, exp. 30. Solicitud del marqués de Mos, Ildefonso Correo Sotomayor y Pinto, conde de San Bernardo, 19 de mayo de 1815.

56 A diferencia de Francia, donde Luis XVIII mantuvo los títulos de nobleza conferidos por Napoleón mientras la antigua nobleza retomaba los suyos y ambos grupos se encontraban representados en la Cámara de Pares, como seńala Pantoja (2017): 22.

57 AGP, Fernando VII, caj. 398, exp. 29. El marqués lo solicitó el 2 de junio y, en principio se le señaló una fecha, pero al investigarse más se le denegó inmediatamente. 
La espinosa cuestión del abono de lanzas y medias anatas volvió a debatirse en la junta de 2 de mayo de 1816, al publicar La Gazeta de Madrid una circular del Ministerio de Hacienda a sus intendentes y subdelegados, urgiéndoles al pronto cobro de dichos impuestos. La orden partía del rey, al haber comprobado que — desde hacía décadas - numerosos magistrados habían permitido que nobles hubieran tomado posesión de sus títulos, cargos y prebendas sin haber presentado certificado de abono en la Contaduría de Valores. Ya se había ordenado anteriormente su cobro, por Reales Órdenes de 25 de julio de 1815 y de 12 de abril de 1815, en que se denegaron compensaciones. Como no se habían ingresado dichas cobranzas, Fernando VII ordenó que se cumplieran escrupulosamente, bajo pena, en un plazo de quince días, negándose a admitir la solicitud de la Diputación de Grandes de abonar el adeudo entregando vales reales y anulando la orden de 2 de septiembre de 1800 , que abría esa posibilidad ${ }^{58}$. En la citada junta, los presentes aprobaron elevar al rey la solicitud de modificación de dicha circular, que ocupó siete folios y medio en una letra menuda, muestra del conjunto de razones sobre los cuales intentaron defender su postura contraria.

Comenzaron su escrito denunciando cómo la primera clase del Estado venía recibiendo críticas y maquinaciones contra su imagen labrada de fidelidad, honradez y probidad, sin verter una queja ante esas tentativas de destrucción. Los grandes y sus parientes venían desempeñando los más importantes cargos y magistraturas relacionadas con la diplomacia, las armas y la política, al ver en ellos hombres íntegros. Señalaron que buena muestra de ello habían sido las continuas peticiones de los pueblos para que se pusieran a su frente en la guerra de la Independencia. Negaron la visión de haberse convertido en una clase ociosa, afeminada, viciosa y sin educación, defendiendo su instrucción, honradez, integridad y ambición de gloria. Asimismo, negaron que la mayor parte de la nobleza luciera sus títulos sin abono de impuestos, salvo excepciones. Bien es cierto que la época de la invasión francesa había dificultado el abono de esos impuestos, pero también había desarticulado la Administración, desapareciendo los magistrados legítimos, mientras las haciendas de la nobleza caían empobrecidas. Recordaron que numerosos nobles colaboraron con el erario y el ejército que luchaba contra el invasor, mientras saqueaban sus casas, incendiaban sus propiedades y arruinaban sus fuentes de riqueza. A esa situación se unieron los decretos de las Cortes extraordinarias citados anteriormente, la

58 «Real orden sobre el considerable descubierto en que se halla el Real servicio de Lanzas y derecho de Media annata por no haberse guardado en su exacción y cobranza lo mandado en la Real cédula de 8 de Mayo de 1789", La Gazeta de Madrid, núm. 55, 30 de abril de 1816, pp. 434-435. 
desposesión de derechos jurisdiccionales y las amnistías concedidas por las autoridades para evitar que casas y propiedades enfitéuticas o arrendadas no fueran abandonadas por sus colonos. Contribuyeron también a arruinar el patrimonio de la nobleza los impuestos ordinarios y extraordinarios, la denegación de sueldos devengados, la falta de pago de todo crédito contra Hacienda, la nulidad de la deuda pública y de las acciones de entidades privadas o estatales.

Lógicamente, no culparon al monarca por sus últimas exigencias, sino a sus malos consejeros que le habían presentado la fortuna de la nobleza totalmente abultada y alejada de la realidad de posguerra. Y la negativa a pagar esos impuestos por medio de vales reales suponía negarles un alivio a todos los sacrificios descritos. Se mostraron ofendidos porque la circular afirmaba que los títulos se ostentaban sin haber cumplido con sus obligaciones fiscales, ya que esa afirmación ofendía a toda la nobleza, perjudicando su imagen y, como leales servidores de la Corona, la de su titular. Los malos consejeros podían poner en peligro el cumplimiento del donativo exigido en $1814-\mathrm{y}$ que la grandeza estaba enviando de diversas formas - por la pequeña suma que se recaudaría de lanzas y medias anatas no abonadas. Y si algunas corporaciones, gremios y bancos se les había eximido de pagos por un tiempo, ¿por qué este apremio a la nobleza? Toda esa presión fiscal podía llevar a numerosos títulos a negarse a asistir en la corte y residir en Madrid por no tener medios para sostener «el decoro de su clase». Por ello solicitaron medidas para poder abonar retrasos con dignidad, aclarar su cuantía de forma realista y conforme a su grave situación económica ${ }^{59}$.

A comienzos del siguiente ańo, el 26 de enero de 1817, el ministro de Hacienda, Martín de Garay, comunicó a la Diputación la resolución regia a su petición, según la cual se ordenaba a grandes y títulos de Castilla que extinguieran sus deudas por lanzas abonando dos anualidades atrasadas y una corriente por cada título, siendo el pago de medias anatas obligatorio antes de expedir sus documentos acreditativos del mismo. No obstante, el rey había aceptado una propuesta de la Diputación para ligar el producto de ciertas rentas a esos abonos, verificándolo legalmente ante los intendentes de cada provincia. Los atrasos de lanzas y medias anatas que se debían hasta fin de diciembre de 1814 pudieron pagarse con vales reales consolidados por todo su valor o, en los no consolidados, con descuentos previamente acordados. Por lo que se adeudaba desde 1815 hasta 1818 se admitió la quinta parte en vales consolidados por todo su valor, y en los no consolidados se permitió abonar con ellos un porcentaje, mientras que el resto fue pagado en moneda ${ }^{60}$.

59 Diputación Permanente (1944): 59-63.

60 Martín de Balmaseda (1833): 524. 
El abono de lanzas redimía a los hijos de los grandes a ser incluidos en quintas, y el propio reglamento de alistamiento de ese año así lo daba a entender. Sin embargo, en algunos lugares no se tuvo en cuenta esta circunstancia, por lo que se elevaron a la Diputación sendas protestas por parte del marqués de Guadalcázar y del príncipe Pío, que —en espera del dictamen a su queja- prefirió que su hijo primogénito sentara plaza voluntariamente en Artillería de Marina antes que ser sorteado junto a sus lacayos. Como el asunto afectaba a toda la grandeza, los vocales solicitaron el mantenimiento del privilegio al rey, el cual lo dio trasladó. Consultado el Consejo Supremo de Guerra, el monarca se avino a su dictamen, que negó la solicitud, confirmando en noviembre de 1818 que los hijos de toda la nobleza estaban comprendidos en la instrucción de reemplazo militar, que preveía, no obstante, librarse del servicio por 20000 reales $^{61}$.

\section{CONCLUSIÓN: UNA ESTRATEGIA POLÍTICA FRACASADA}

Si bien se solicitó la participación de la grandeza en los gastos de las exequias por el alma de la reina Isabel de Braganza ${ }^{62}$, a lo largo de 1819 comenzó a notarse la decepción entre sus representantes por el fracaso de sus ambiciones políticas. La Diputación continuó reuniéndose, pese a la escasa importancia de los asuntos que se despacharon, muchos de ellos protocolarios; el marqués de Cerralbo dimitió como secretario, alegando sus frecuentes ausencias de la capital, y el conde de Bornos no quiso hacerse cargo del puesto por presidir el Consejo de Órdenes, por lo que fue elegido el duque de Medinaceli.

Resulta sintomático que no fuera un grande, sino el asesor Ramón Giraldo quien defendiera en un escrito que debía ser la Diputación un órgano consultivo de la Corona, a cuyo conocimiento no debiera sustraerse. Intentó ahondar, quizá por ello, en su institucionalización, defendiendo la necesidad de crear un archivo para evitar que los expedientes se custodiaran en la casa del secretario, con el consiguiente riesgo de perderse, y buscando un lugar en

61 Sobre los cambios en la milicia y en la armada que afectaron a la tradicional posición de la alta nobleza, hasta la guerra de la Independencia, ver Rodríguez González (2000) y Bullón (2015).

62 Y los grandes contribuyeron. AHN, Osuna, caj.196, doc. 43. Recibo del duque de Medinaceli que acredita que la condesa-duquesa de Benavente, le ha hecho entrega de 2000 reales para cubrir los gastos de las exequias por el alma de la reina, 31 de enero de 1819. 
palacio, donde también se encontraba la sala de juntas, reuniendo así en el archivo pleitos, memorias, documentos y todo lo legislado sobre la grandeza. Su intento fue, finalmente, infructuoso. Ni la Junta General ni su Diputación se constituyeron como una cámara de pares o próceres durante el reinado fernandino, como en Gran Bretańa o Francia.

La vuelta al sistema constitucional durante el Trienio Liberal (18201823) ayudó todavía más a disminuir la posibilidad de participación de la Diputación de la Grandeza en la escena política, aunque el rey volvió a solicitarle que organizara donativos ${ }^{63}$. Se decidió celebrar sus reuniones fuera del Palacio Real, en casa del duque de Medinaceli, durante esos años. No obstante, los grandes siguieron sirviendo en la Real Casa, el Ejército, en corporaciones municipales y de beneficencia. Pero algunos de ellos sufrieron la política liberal de purificación política del entorno del monarca, por lo que tuvieron que abandonar sus puestos palatinos ${ }^{64}$. La Administración, por su parte, continuó reclamándoles los pagos de lanzas y medias anatas ${ }^{65}$.

Tras la huida del Gobierno liberal a Andalucía por el avance de los Cien Mil Hijos de San Luis el 28 de mayo de 1823, 31 grandes firmaron una «Exposición presentada a S. A. R. el Sr. Duque de Angulema por la Grandeza de España» donde le manifestaron su gratitud por encabezar la intervención militar francesa cuyo objetivo era deshacer el sistema constitucional y devolver la plenitud soberana a Fernando VII. En sus últimas líneas se ofrecieron a cooperar en esta empresa, ofreciendo sus vidas y haciendas «para su buen éxito» ${ }^{66}$.

El Gobierno, refugiado en Cádiz con la familia real, autorizó la publicación en La Gaceta Española de la exposición, anotando serias críticas a la misma. De esta manera, señalaron que sus firmantes no componían la mayoría de la grandeza, ni por sus talentos ni por sus virtudes. Recordaron a los lectores que la nación jamás había esperado ningún bien de esos nobles, pues les

63 El monarca solicitó un nuevo donativo a la grandeza para paliar los graves estragos de la epidemia de fiebre amarilla en los últimos meses de 1819 y, a través del secretario de Hacienda, otro para hacer frente a los problemas de este ministerio en marzo de 1820, tres días antes de jurar la Constitución de 1812. Diputación Permanente (1944): 115-118.

64 Tema pormenorizadamente analizado en Moral (2005): 77-102.

65 AGP, Fernando VII, caj. 176, exp. 29. El 1 de abril de 1823, el intendente de Madrid ordenó que a tres grandes que debían lanzas se les retuviera determinadas cantidades de dinero del sueldo que cobraban de la tesorería real por ocupar cargos en la corte, precisamente para cubrir esas deudas. Concretamente, a la condesa de Alcudia (camarera mayor), al marqués de Pejas y al conde de Torrejón (mayordomo mayor de la reina hasta 1820 ).

66 Gaceta Española, Cádiz, sábado, 5 de julio de 1823: 298-299. 
relacionaron con la corrupción social y la traición, al rebelarse contra su rey y su patria. Definiéndoles como "facción siniestra y poco numerosa» ${ }^{67}$, les recriminaron que tuvieran que pedir ayuda a las bayonetas extranjeras para hacer triunfar su vergonzosa cobardía. Y, nuevamente, al sorprenderse de que pudieran dar lecciones de moral o de conducta religiosa algunos de los y las firmantes, recuperaron la imagen de nobles inmorales y decadentes, propia de la Revolución francesa ${ }^{68}$.

El ofrecimiento final realizado al duque de Angulema trató de materializarse en la Junta General que se organizó el 20 de junio en Madrid. El conde de Puñonrrostro avaló personalmente la idea de levantar un ejército de entre 8000 y 12000 espańoles, pagado por la grandeza, para unirse a los franceses en su lucha contra las fuerzas liberales. Su proyecto contó con el apoyo de los presentes, por lo que la Diputación intentó conseguir un empréstito bajo la garantía de ciertos bienes de varios grandes. Sin embargo, los banqueros no consideraron garantizadas unas hipotecas que se establecerían sobre bienes vinculados, muchos de los cuales estaban bajo la observación del fisco. La Corona, en ausencia de su titular, no podía avalar el derecho de los acreedores, por lo que Angulema les hizo desistir de sus propósitos cortésmente ${ }^{69}$.

Al conocerse la liberación de la familia real en el Puerto de Santa María el 1 de octubre de 1823, que sellaba el final del Trienio Liberal, una Junta General de la Grandeza acordó celebrar una solemne función de acción de gracias, que sería sufragada por todos sus componentes, así como la impresión y circulación de la Real Cédula sobre reintegración de señoríos territoriales y solariegos de 11 de marzo de 1824. El gesto no pudo ser más elocuente de las esperanzas que depositaron, nuevamente, en la restauración de la plena soberanía regia para recuperar un mecanismo ligado a su supervivencia: el mayorazgo. Las Cortes liberales habían legalizado la desvinculación que suprimía los mayorazgos y vinculaciones, obligando a repartir las propiedades de una familia noble entre todos sus herederos legítimos, permitiendo su enajenación al desvincularlas de un linaje. La citada real cédula anulaba la legislación liberal y obligaba a devolver a sus antiguos dueños los bienes vinculados ${ }^{70}$. Sin embargo, no parece que supusiera una mejora económica inmediata pues numerosos grandes - en su correspondencia con la Diputación - adujeron tener la mayor parte de sus rentas embargadas para responder del pago de lanzas y media anata o retenidas por orden judicial, de ahí que de 122 grandes

\footnotetext{
Ibid., nota 1 al texto.

Ibid., notas 9 y 10 al texto.

Diputación Permanente (1944): 121-122.

Rueda (2015): 52-53.
} 
tan solo 36 se hallaran al corriente del pago de cuotas para gastos y asesoría de la Diputación. La actuación de la Junta matiza, pues, el debate historiográfico sobre la desvinculación, pues, si bien fue imposible frenar su aplicación, no por ello la nobleza optó por un papel meramente espectador.

La actuación política de los grandes durante el Trienio recibió una enérgica respuesta de Fernando VII al realizar la depuración interna de la servidumbre de la Real Casa y Patrimonio. Fueron defenestrados de la corte aquellos miembros de la grandeza que mostraron tibieza, discreción o excesiva adaptación con el caído régimen liberal. Por ejemplo, se le retiró la llave de gentilhombre al conde de Fuentes, quizá por no haber impedido el traslado forzado de la familia real a Sevilla, siendo comandante de la Guardia Real; abandonaron la capital el marqués de Cerralbo, el conde de Sástago, el marqués de Alcañices y el de Villafranca; fueron expulsadas del servicio de damas de la reina la marquesa de Mos, la señora de Rubianes y la condesa de Altamira; el duque de Noblejas y el marqués de Santa Cruz fueron encarcelados, aunque — por presión del Cuerpo Diplomático- se trasladaron arrestados a sus casas. En definitiva, unos 39 grandes y títulos fueron expulsados, lo que supuso el 10,5\% del total de servidores depurados ${ }^{71}$.

O se perdieron sus testimonios escritos o no se despachó ningún asunto relevante durante el resto de la Década Absolutista, si se acepta la versión del autor de los Apuntes de 1934. Lo cierto es que tampoco se conservan muchos más documentos en el Archivo General del Palacio Real de Madrid. Cabe subrayar el hecho de que no se celebraran coberturas de la grandeza durante los tres años del régimen constitucional ni en la inmediata restauración.

TABLA 2. Coberturas de grandes (enero de 1825-junio de 1833)

\begin{tabular}{ccccc}
\hline Año & $\begin{array}{c}\text { Grandes } \\
\text { de } 1 .{ }^{a} \text { clase }\end{array}$ & $\begin{array}{c}\text { Grandes } \\
\text { de } 2 .{ }^{a} \text { clase }\end{array}$ & $\begin{array}{c}\text { Solicitan exención } \\
\text { de gastos }\end{array}$ & $\begin{array}{c}\text { Se concede } \\
\text { la exención }\end{array}$ \\
\hline 1825 & 3 & - & - & - \\
\hline 1826 & 11 & 3 & 9 & - \\
\hline 1827 & 2 & - & - & - \\
\hline 1830 & 11 & 2 & 4 & - \\
\hline 1833 & 7 & 2 & 2 & - \\
\hline
\end{tabular}

Fuente: AGP, Fernando VII, caj. 398; caja 73, exp.3 y Libro registro 4945.

71 Moral (2005): 103-111. 
De forma intermitente, se concentraron la mayoría de las coberturas en dos años, como se aprecia en la tabla 2. En la concesión de grandezas poco tuvo que ver la Diputación, pues las continuó acordando el monarca a través de la Primera Secretaría de Estado. Sus vocales solicitaron al rey que se considerasen válidos para el pago de lanzas los juros posteriores a 1803, a lo que el monarca, consultado el Consejo de Hacienda, respondió accediendo parcialmente, pues solo se aceptarían los juros consignados en la Real Cédula de 20 de enero de $1828^{72}$. Y ante la crisis sucesoria que se produjo tras el cuarto matrimonio de Fernando VII y el nacimiento de sus hijas, la Diputación continuó considerando al infante don Carlos su vicepresidente, pese a la tensión imperante en la corte. Algunos nobles intentaron renunciar a su elección como vocal de la Diputación, lo que transparentó, nuevamente, el concepto de utilidad que tenían de la misma y el fracaso final de una ambición política ${ }^{73}$. Tras la muerte del rey, la Diputación envió al primer secretario de Estado una declaración de fidelidad, reconociendo como legítima sucesora a Isabel II y manifestando su disposición a obedecer a la reina gobernadora ${ }^{74}$.

Se abría una nueva etapa en la historia de la Diputación, que continuaría intentando participar en el nuevo régimen isabelino, y donde la creación de un Estamento de Próceres y, posteriormente, de un Senado, tal vez pudieran convertirse en una nueva oportunidad política para la grandeza ${ }^{75}$. Finalizó así una maniobra iniciada en 1815 que no dudamos en encuadrar en las llamadas «reacciones aristocráticas» que tuvieron un carácter periódico en la larga transición del Antiguo al Nuevo régimen, según Mosse $^{76}$. Si bien —en esa épocalos nobles terratenientes dominaron aparentemente el escenario político inglés y la alta Administración rusa estaba ocupada mayoritariamente por miembros de ese mismo grupo social, al igual que la alemana, resultó necesario una reafirmación de la identidad nobiliaria que justificara su presencia política, especialmente tras el huracán revolucionario. En el caso de España, la creación de la Junta de Grandes fue percibida como una herramienta para lograrlo por parte de algunos de sus componentes. Ser noble implicaba una vida de esplendor, y ella grandes ingresos, de ahí la preocupación por preservar sus

Gaceta de Madrid, n. 54,30 de abril de 1831, p. 225.

73 AGP, Fernando VII, caj. 75, exp. 53. Cuatro vocales, elegidos en 1832, alargaron su negativa hasta que la reina gobernadora María Cristina dictó su resolución a finales del siguiente año.

74 Gaceta de Madrid, n. ${ }^{\circ} 124,10$ de octubre de 1833, p. 534.

75 Pese al estudio de Alós y Merry del Val (2000), todavía existen temas por analizar sobre la actuación política de la nobleza en este organismo.

76 Mosse (2000): 140. 
fuentes de riqueza que se transparentaron en la Junta. Por todo ello, los intentos de la alta nobleza española por influir corporativamente en el escenario político demostraron ser más tenaces de lo que, hasta el momento, se había pensado.

\section{Bibliografía}

Alarcón Alarcón, M. M. (2012). Las relaciones entre la corona y la aristocracia española durante el reinado de Carlos IV: el caso del XIII duque del Infantado (1791-1808). Pasado y Memoria, 11, 165-186. Disponible en: https://doi.org/10.14198/PASADO2012.11.08.

- (2015). Biografía histórica de Pedro Alcántara de Toledo y Salm-Salm, duque del Infantado (1768-1841) [tesis doctoral]. Universidad de Alicante.

Alós y Merry del Val, F. (2000). La nobleza en el Estamento de Próceres, 1834-1836. Madrid: Gráficas Roma.

Barrios Pintado, F. (2016). La media anata de los palatinos: su aplicación en el reinado de Felipe IV. En R. Valladares Ramírez, F. Barrios Pintado, J. A. Sánchez Belén (coords.). En la Corte del Rey de España: liber amicorum en homenaje a Carlos Gómez-Centurión Jiménez (1958-2011) (pp. 181-206). Madrid: Polifemo.

Beckett, J. (1988). The Aristocratic Contribution to Economic Development in Nineteenth Century England. En Les noblesses europénnes au XIXe siècle. Actes du colloque de Rome (pp. 281-296). Rome: École Française de Rome.

Bullón de Mendoza, A. (2014). Nobleza y política en la Espańa contemporánea, 1788-1931. En Grupo de Estudio de Historia de la Nobleza (ed.). La nobleza española, 1780-1930 (pp. 77-116). Santander: Rh+ Ediciones.

(2015) Nobleza y milicia en la España contemporánea (1788-1939). Aportes. Revista de Historia Contemporánea, 89, 59-79.

Carmona Vidal, J. (2001). Aristocracia terrateniente y cambio agrario en la España del siglo XIX. La Casa de Alcañices (1790-1910). Ávila: Junta de Castilla y León.

Carrasco Martínez, A. (1995). Estrategias y actitudes aristocráticas en España a finales del Antiguo Régimen. Historia Social, 23, 65-78.

(2006). El XIII duque del Infantado, un aristócrata en la crisis del Antiguo Régimen. En la España Medieval, 1, 305-336.

Cruz, J. (1994). Notability and revolution: social origins of the political elite in liberal Spain. 1800 to 1853. Comparative Studies in Society and History, 36 (1), 97-121. Disponible en: https://doi.org/10.1017/S0010417500018909.

(1996). Gentlemen, bourgeois and revolutionaries. Political change and culture persistence among the Spanish dominant groups, 1750-1850. Cambridge: Cambridge University Press.

Cuenca Toribio, J. M. y Miranda García, S. (1998). Nobleza y poder ejecutivo en la España contemporánea. Historia Contemporánea, 17, 159-168.

Daumard, A. (1988). Noblesse et aristocratie en France au XIXe siècle. En Les noblesses europénnes au XIXe siècle. Actes du colloque de Rome (pp. 81-104). Rome: École Française de Rome. 
Diputación Permanente y Consejo de la Grandeza de España (1944). Apuntes del Archivo, 1815-1864. Madrid: E. Giménez S. A.

García Monerris, C. (2002). Señorío. En J. Fernández y J. F. Fuentes (dirs.). Diccionario politico y social del siglo XIX español (pp. 644-647). Madrid: Alianza Editorial.

Hernández Montalbán, F. (1999). La abolición de los señorios en España (1811-1837). Madrid: Biblioteca Nueva.

La Parra, E. (2007). De la disputa cortesana a la crisis de la Monarquía. Godoyistas y fernandinos en 1806-1807. Cuadernos de Historia Moderna. Anejos, 6, 255-267.

(2010). Los hombres de Fernando VII en 1808. En A. Alberola y E. Larriba (eds.). Las élites y la revolución de España (1808-1814) (pp. 127-152). Alicante: Universidad de Alicante.

- (2014). La restauración de Fernando VII en 1814. Historia Constitucional, 15, 205-222. (2018). Fernando VII. Un rey deseado y detestado. Barcelona: Tusquets.

Martín de Balmaseda, F. (1833). Colección legislativa de España. Decretos del rey Fernando VII. Compilados por... (vol. 5). Madrid: Imprenta Real.

Martínez Quinteiro, M. E. (1977). Descontento y actitudes políticas de la Alta Nobleza en los orígenes de la Edad Contemporánea. Hispania, 135, 95-138.

Moral Roncal, A. M. (2001). Bases para el estudio de la nobleza en la Real Sociedad Económica Matritense de Amigos del País (1775-2000). Torre de los Lujanes, 45, 243-269.

_ (2002) La nobleza americana en la corte de Fernando VII (1814-1833). Trienio. Ilustración y Liberalismo, 30, 63-80.

(2005). ¡El enemigo en Palacio! Afrancesados, liberales y carlistas en la Real Casa y Patrimonio (1814-1843). Alcalá de Henares: Servicio de Publicaciones de la Universidad de Alcalá.

- (2015). La nobleza española en la política y diplomacia durante la Edad Contemporánea. Aportes, Revista de Historia Contemporánea, 89, 81-113.

Morange, C. (1984). El conde de Montijo. Reflexiones en torno al partido aristocrático de 1794 a 1814. Trienio. Ilustración y Liberalismo, 4, 33-67.

Mosse, W. (2000). Aristocracia y burguesía en la Europa del siglo xix. Un análisis comparativo. En J. Fradera y J. Millán (eds.). Las burguesías europeas del siglo XIX (pp.133-168). Madrid: Biblioteca Nueva.

Pantoja Morán, D. (2017). La experiencia de la Restauración en Francia como paso al sistema parlamentario de gobierno. Estudios Políticos, 41, 11-16. Disponible en: https://doi. org/10.1016/j.espol.2017.05.003.

Powis, J. (2007). La aristocracia. Madrid: Siglo XXI: Real Maestranza de Caballería de Ronda.

Pro Ruiz, J. (1994). Aristócratas en tiempos de constitución. En Antiguo Régimen y revolución liberal. Homenaje a Miguel Artola. Tomo II. Economia y sociedad. (pp. 615-630). Madrid: Alianza.

- (1995). Las élites de la España liberal: clases y redes en la definición del espacio social (1808-1931). Historia Social. 21, 47-69.

Risco, A. (2010). Avatares de la nobleza afrancesada y liberal. En A. Alberola y E. Larriba (eds.). Las élites y la revolución de España (1808-1814) (pp. 187-206). Alicante: Universidad de Alicante. 
Rodríguez González, A. (2000). La aristocracia en la Armada española durante la Edad contemporánea (1789-1980). Aportes. Revista de Historia Contemporánea, 44, 107-130.

Rueda Hernanz, G. (1997). La desamortización en España: un balance (1766-1930). Madrid: Arcolibros.

- (2014). Los nobles en el periodo ilustrado y liberal, 1780-1930. En Grupo de Estudio de Historia de la Nobleza (ed.). La nobleza española, 1780-1930 (pp. 11-38). Santander: $\mathrm{Rh}+$ Ediciones.

- (2015). La supresión de señoríos y el proceso desvinculador de los bienes nobiliarios. Aportes. Revista de Historia Contemporánea, 89, 41-58.

Ruiz Torres, P. (1988). La aristocracia en el País Valenciano: la evolución dispar de un grupo privilegiado en la España del siglo xIx. En Les noblesses europénnes au XIXe siècle. Actes du colloque de Rome (pp. 137-163). Rome: École Française de Rome.

Sánchez Marroyo, F. (2014). Riqueza y familia en la nobleza española del siglo XIX. Madrid: Ediciones 19.

- (2015). Las economías nobiliarias en el siglo xIx. El protagonismo de las rentas agrarias. Aportes. Revista de Historia Contemporánea, 89, 5-39.

Sanz Ayán, C. (2011). El canon a la nobleza en la Monarquía hispánica: la media anata de mercedes. En A. Marcos Martín (coord.). Hacer historia desde Simancas homenaje a José Luis Rodríguez de Diego (pp. 705-726). Valladolid: Junta de Castilla y León.

Tudesq, A. (1988). L'élargissement de la noblesse en France dans la première moitié du XIXe siècle. En Les noblesses europénnes au XIXe siècle. Actes du colloque de Rome (pp. 121-135). Rome: École Française de Rome.

Wasson, E. (2006). Aristocracy and the Modern World. New York: Palgrave Macmillan. Disponible en: https://doi.org/10.1007/978-1-137-04029-9. 